\title{
Gamified Learning: Are Vietnamese EFL Learners Ready Yet?
}

\author{
https://doi.org/10.3991/ijet.v15i24.16667 \\ Thi Thanh Huyen Phuong \\ FPT University, Hanoi, Vietnam \\ huyenptt3@fe.edu.vn
}

\begin{abstract}
Given the strong empirical evidence, which confirms the relationship between the use of game elements and increased learning motivation, gamification has recently become a concept that starts drawing attention in the field of English language teaching (ELT). However, gamified learning is still under-presented in ELT research. The current research explores the extent to which Vietnamese learners of English are ready for and their attitudes toward online-based gamified learning. The study draws on data collected from survey questionnaires with 147 students and focus groups with 12 students. The findings indicate that gamification has started taking a certain role in English learning both within and beyond classrooms in the context of the study. Students are technologically well-prepared for online-based gamification and hold positive attitudes towards gamified learning. However, online gamification is being mainly used to assist vocabulary learning.
\end{abstract}

Keywords-EFL pedagogy, gamification, gamified learning, learners' perspectives

\section{Introduction}

In today's world, the most challenging task that faces teachers in general and English teachers in particular is to motivate and engage learners in learning. Gamification has been found to be one of the ways to do so effectively in education [1][2][3]. The era of blooming technology has brought about an unprecedented opportunity for the application of this pedagogical approach with the availability of abundant online game platforms and smart devices. In English-as-a-foreign-language (EFL) contexts, however, the application of gamification is assumed to face several constraints including tight curriculum, teachers and learners' limited access to hi-tech facilities, their unfamiliarity with gamification, also their attitudes towards the approach. However, the status of gamification in EFL classrooms was little known due to limited research in the field.

In Vietnam, English teaching methods have sometimes been reported as a major demotivating factor for learners [4]. The strong encouragement of the Vietnamese government for the use of information technology (ICT) in education [5] should be favorable for teachers to transform the perceived "tedious" traditional classroom 
practices. Counterintuitively, no research attention directed at the topic of gamification in Vietnamese ELT to date. Furthermore, [6] claimed that learners' experience in gamified learning has been rarely investigated from a qualitative perspective. To bridge the gap in literature, the current research explores the extent to which learners in Vietnam are ready for and their attitudes towards online-based gamified learning. The research draws mainly on qualitative data from focus groups which is illuminated with some quantitative data from questionnaires. The research focuses on three research questions:

1. To what extent are Vietnamese EFL learners technologically prepared for and familiar to online-based gamification?

2. In which aspects of English language is online-based gamification used to assist learners' learning?

3. What are learners' perspectives of the effectiveness of online-based gamification in their English learning?

\section{Gamification in Education}

The concept of "gamification", adding game mechanics and game elements in nongame contexts [7], has recently been introduced and quickly gained its ground in several aspects of life. In education, gamification is an emerging approach and attracting much research attention [8][9]. Gamification means to extract, adapt and apply game elements such as points, badges, leaderboards in teaching process to make learners motivated in learning, feeling "as if they were playing a game" [10].

Gamification is strongly believed to be an effective learning environment thanks to its capacity to motivate and engage learners [1][2][11][12][13][3]. In addition, this pedagogical approach is also found to promote not only learners' transversal skills such as collaboration [14] and problem-solving skills [15] but also specific skills in particular domain of knowledge [16][12][13]. Though the effectiveness of gamification in general in learning enhancement remains to be proven due to mixed research findings, several specific aspects of gamification and certain game platforms have been found to promote learning (see, for example, [17]).

Despite the promising potential of gamification, the application of the approach in education is not without constraints. It is claimed that teachers in several contexts are not well equipped with appropriate methodology, technical skills [16] and may not have sufficient technical support [12] to apply this approach effectively. Teachers' and learners' attitudes towards gamification are another factor that may lead to either the success or failure of gamification in a particular context.

\section{Gamification in Language Teaching}

The use of gamification should be more relevant in language teaching than in any other aspects of education given that games have long been part of foreign language pedagogy. When surveying teachers in different countries for their experiences and 
perspectives of the application of games, [18] finds that the learning potential brought about by gamification in language classes is perceived by teachers as higher than in other subjects. Nowadays, the burgeoning use of ICT in language education would be a firm premise for gamification to thrive.

Despite the lack of ELT research on gamification to date, advantages of gamification in EFL classrooms have recently confirmed. [19] finds that gamified activities help to reduce EFL learners' anxiety and improve their grammar performance. Besides, young EFL learners' language acquisition is boosted and learning distraction is reduced in gamified environment [20]. [21] explores EFL teachers and learners' views of the use of gamification at primary education in Hong Kong and gets positive findings of the perceived effectiveness of gamification in engaging, motivating learners and boosting learners' confidence and learning outcomes. However, most of the studies on gamification in EFL world, apart from Zou's [21], investigates the effectiveness of specific games or game platforms basing on quantitative data collected from tests. This suggests that qualitative research on teachers and learners' views of gamification would add valuable insights into the topic.

\section{$4 \quad$ Methodology}

The current research is a part of a bigger project which investigates the use of ICT in Vietnamese English classrooms and draws upon a subset of the data collected via survey questionnaires and focus groups. The survey questionnaires were adapted from that developed by [22] to investigate teachers and learners' perspectives of English pronunciation pedagogy in Europe. The survey consists of three main parts with the total of 255 -point Likert-scale items and involve 147 students who were in the last semester of a 6-month English preparation course (EPC) at a private technology university in Hanoi. In the survey, the section on gamification, which the current research draws upon includes nine questions. The survey link was sent to students via their institutional email addresses. The data collected was automatically processed by Google Forms.

Twelve volunteers among surveyed students joined focus-group interviews, each of which consisted of four students. During focus groups, students were invited to discuss about their experience with online-based gamified activities and the perceived effectiveness of this approach. The length of focus groups ranged between 40 minutes and an hour. Given that the first language would significantly facilitate one's understanding of survey questions and in-depth discussions about a certain topic, Vietnamese is chosen as the language for both the survey and the focus groups. The prominent patterns emerging from survey data function to guide the in-depth exploration conducted via the focus groups afterwards. All focus groups were audio recorded and interview data were coded manually and analyzed thematically by the author. 


\section{$5 \quad$ Findings}

\subsection{Learners' technical readiness for online-based gamification}

As can be seen in Table.1, students are quite technologically ready for online gamified activities with $95 \%$ of participants claiming to possess either a smartphone or an internet-connected computer. All respondents could frequently get access to internet at school and 93\% could do so at home (see Table.1). At focus groups, students disclosed that owning a laptop is a must for them to join class activities, get access to learning materials and do tests, which were all highly web-based at this university. Regarding learners' internet using skills, all students at focus groups indicated high confidence in their web-browsing skills. Some students, including Minh, Thuong, Mai even claimed those skills as their prominent strengths.

Table 1. Learners' access to technological devices and internet

\begin{tabular}{|l|c|}
\hline \multicolumn{1}{|c|}{ Statements } & Agree/Strongly Agree \\
\hline I own a smart phone or an internet-connected computer & $100 \%$ \\
\hline I can get access to internet at school on frequent basis & $100 \%$ \\
\hline I can get access to internet at home on frequent basis & $93 \%$ \\
\hline
\end{tabular}

\subsection{Learners' familiarity with online language games}

Survey data indicate that online language games were quite familiar with the vast majority of the students. Table 2 shows that half of the surveyed often or very often played one or some online language games to learn English at home. Thirty nine percent sometimes played those games and those who rarely or never did so make up a small proportion of $10 \%$. Students' exposure to language games in the classroom was even greater. Ninety four percent of students claimed to (very) often or sometimes play language games in classrooms while only $5.5 \%$ disclosed that they rarely or never did so.

Table 2. Frequency of learners' exposure to online-based gamified learning

\begin{tabular}{|l|c|c|c|c|c|}
\hline \multicolumn{1}{|c|}{ Questions } & $\begin{array}{c}\text { Very } \\
\text { often }\end{array}$ & often & Sometimes & Rarely & Never \\
\hline $\begin{array}{l}\text { How often do you play an online language } \\
\text { game at home to learn English? }\end{array}$ & $14.5 \%$ & $35.8 \%$ & $39.3 \%$ & $8.2 \%$ & $2.1 \%$ \\
\hline $\begin{array}{l}\text { How often do you play an online language } \\
\text { game in the classroom to learn English? }\end{array}$ & $22.1 \%$ & $42.1 \%$ & $29.5 \%$ & $4 \%$ & $1.3 \%$ \\
\hline
\end{tabular}

Focus group data reveal that games in use in the context of this study including Kahoot, Quizziz, Quizlet. Among the mentioned online games, most participants said they only played Quizlet at home because it is "suitable for self-study" (Phuong-F3). Other games such as Kahoot and Quizziz were said to "involve a lot of competition and excitement and we enjoy playing them in class better. It is more fun and stimulating to play and compete with people physically present around" (Minh- F1). The use 
of online language games in class was reported to highly depend on each individual teacher. Van (F3) said "it is hard to say how often games are used in our classes because some teachers used them very frequently while some others rarely or never do".

It seems that the decision on which game to apply in class also vary among teachers. A student, Mai (F2) said that each of her teachers preferred a certain game: "While Mrs. Anh often use Quizlet, Mr. Chen never uses that game. He often uses Quizziz instead".

\subsection{Aspects of English assisted with gamified activities}

Data from both focus groups and survey indicate that online games are mostly used to teach vocabulary. According to survey results, $85.5 \%$ students said that games were used to assist the learning of English vocabulary while only $11.8 \%$ and $3.8 \%$ mentioned the use of games to teach content knowledge, and English grammar respectively. No participant reported the use of online games in teaching and learning other aspects of English. In focus group data, only one student (Thuong-F1) recalled an instance in which his teachers used Kahoot to teach how to write a topic sentence of a paragraph.

Table 3. Aspects of English assisted with online gamification

\begin{tabular}{|l|c|c|c|c|c|}
\hline \multicolumn{1}{|c|}{ Statements } & Vocab & Grammar & Writing & $\begin{array}{c}\text { Content } \\
\text { knowledge }\end{array}$ & Others \\
\hline $\begin{array}{l}\text { What aspect(s) of English are } \\
\text { online games used to facilitate } \\
\text { your learning? }\end{array}$ & $85 \%$ & $11.8 \%$ & $0 \%$ & $3.8 \%$ & $0 \%$ \\
\hline
\end{tabular}

\subsection{Learners' perception of online language games}

A major theme emerging from collected data is a strong favor towards online language games. In response to the question "What is your experience with the online language games you have played like?", the majority of the students (57\%) indicated a positive view, $28 \%$ expressed a neutral view and $14 \%$ provided a negative evaluation (see Table 4). Regarding the effectiveness of online language games, $66 \%$ of surveyed students indicated their agreement or strong agreement with the statement that "The use of online games effectively enhances my English learning" and only $11 \%$ disagreed or strongly disagreed with the statement (see Table 5). At the focus groups, online games were frequently associated with positive adjectives such as "fun" (Hieu-F3; Thuong, Minh -F1), "interesting" (Thuy, Phuong -F3; Thuong-F1), "relaxing", "great" (Minh, Thuong-F1; Van-F3; Hang-F2). Students quoted several reasons for their favor of online language games. Some mentioned the appealing presentation of the games with "colorful surface" (Thuy-F3; Truc-F3; Minh -F1), motivating music (Thuy, Phuong-F3; Thuong, Minh -F1), competitive nature (10 students). Especially, nine students strongly confirmed that their English learning is "very much assisted with online language games" (Truc-F3). Notably, six students mentioned the bonus that teachers often gave students in the leaderboard as a signifi- 
cant source of motivation for them to join the games. On this issue, a representative student, Phuong (F3), said "without those bonuses, many of us may feel less motivated to play the games. Games are fun but you know marks are important when we go to school (laugh)". Another student, Thuy, added that "if I know there is a game in the next class, I will revise the lesson more carefully at home to get top scores and get bonus".

However, it also emerges from the finding that games need to be carefully designed to be effective. Truc (F3) revealed that when "I recognize that I cannot get into the leaderboard because my score is too low, I want to quit the game in the middle". Commenting on the effectiveness of the games, Hieu (F3) complained that one of his teacher sometimes organized games right after the new knowledge was introduced, and so "students have not enough time to digest the knowledge and so not ready for the game". Thus, Hieu raised his concern over the effectiveness of gaming in such situations because it was not properly organized: "I don't think the game is useful". As indicated in this comment, the matter of how and when to organize the games may require thoughtful consideration from teachers as it may strongly affect the perceived effectiveness of the game and also learners' satisfaction with the gamified learning.

Table 4. Learners' general impression of online language games

\begin{tabular}{|l|c|c|c|}
\hline \multicolumn{1}{|c|}{ Statements } & Positive & Neutral & Negative \\
\hline $\begin{array}{l}\text { What is your experience with the online language } \\
\text { game(s) you have played like? }\end{array}$ & $57 \%$ & $28 \%$ & $14 \%$ \\
\hline
\end{tabular}

Table 5. Learners' perception of the effectiveness of online language games

\begin{tabular}{|c|c|c|c|c|c|}
\hline \multicolumn{1}{|c|}{ Statements } & $\begin{array}{c}\text { Strongly } \\
\text { agree }\end{array}$ & Agree & Unsure & Disagree & $\begin{array}{c}\text { Strongly } \\
\text { disagree }\end{array}$ \\
\hline $\begin{array}{l}\text { The use of online language games im- } \\
\text { proves the effectiveness of my English } \\
\text { learning. }\end{array}$ & $14.5 \%$ & $51.1 \%$ & $23.5 \%$ & $7.5 \%$ & $3.4 \%$ \\
\hline
\end{tabular}

\section{Discussion}

This study shows that students in the context of this study were technologically well-prepared for the application of gamification. This finding resonates Nguyen's [5], which indicates high availability of internet and smart devices for Vietnamese university students, who also possess good competence in computer and webbrowsing skills. Secondly, gamified learning via online games has been applied frequently both within and beyond classrooms with higher frequency for the former. However, gamification does yet seem an official component of English curriculum and, thus, presented often in some teachers' classes but absent in those of others. Notably, the finding that games such as Quizlet being voluntarily included by students in their self-study at home suggests the appeal and potential of gamification in changing learning behaviors.

Despite the frequent use of online language games, this form of gamified activities is currently deployed mainly to teach vocabulary. This limited application suggests 
that teachers may have more difficulties in applying this approach in teaching aspects of English rather than vocabulary, and may need guidance to fully cultivate the potential of gamification in their teaching practices. Illuminating this finding, [16] claims that adequate methodology is essential for teachers to successfully apply gamification.

Regarding the effectiveness of online language games in enhancing learning, learners generally showed positive evaluation, which resonates Hong Kong learners in Zou's study [21]. However, $14 \%$ of surveyed students indicated negative experience with online language games and $11 \%$ perceived gamification as of little effectiveness. At focus groups, some of students' comments showed that poor preparation in game planning and designing may lead to the limited effect of gamified activities. As discussed earlier in the literature review, though it is widely claimed that gamification is highly effective in engaging and motivating learners, the effectiveness can only be guaranteed if conducted "under appropriate conditions" [14]. Further research, thus, should be conducted to get more insight of learner's needs in gamified learning so that teachers can design gamified activities in a way that maximize learners' positive experience and so maximize the potential of gamified learning.

Another finding that is worth comments is that gaming elements such as badges, leaderboard can be a source of motivation but also of demotivation for learners at the same time. This drawback of gamification is already acknowledged by [10] and [2] . The question raised here is what teachers can do to motivate other forms of learners' intrinsic motivation when joining the games so that the meaning of playing is not just restricted by the matter of winning or losing, but by the senses of, for example, social interaction, being challenged and knowledge gaining. This task may require much work from not only researchers who need to explore how features of games can trigger different aspects of learners' motivation but also teachers who should foster different aspects of their learners' motivation in online language games so as to maintain their engagement and maximize their learning.

\section{Conclusion}

In such a digital era that we have deeply immersed into today, young generations have not only grown up with a huge capacity to play computer games but also enjoyed the experience immensely; not applying games in education is, thus, a waste of a favorable condition [1]. The current research shows that Vietnamese learners of English warmly welcomed gamified learning and highly appreciated the effectiveness of this pedagogical approach. Erenli [23] claimed that if the demand for gamification is raised among learners, teachers should properly respond to the demand even though they may not be keen advocates of gamification. As such, the current research confirms Vietnamese EFL learners' strong favor of gamification in the forms of online language games. It suggests that this demand should be properly responded by teachers and curriculum designers. The findings also suggest that gamification is an approach that bears a great potential which should be cultivated in such EFL contexts as Vietnam to make English education more motivating and fruitful. To best exploit this pedagogical approach, it is necessary that gamification be given with a place in 
English curriculum and sufficient training be provided to teachers so they are wellprepared to use gamification effectively.

\subsection{Limitations}

The current research bears some limitations. Firstly, the research scope is limited to learners' views regarding the potential of gamification in Vietnamese EFL classrooms. Further research should be conducted to investigate EFL teachers' willingness and readiness in pursuing this newly emerging pedagogical approach as well. Findings of such studies would better inform curriculum makers and educational administrators about whether or not gamification should be incorporated into English curriculum in their contexts. This is also a good source of information about what teachers may be in needs of to apply this pedagogical approach fruitfully.

Secondly, the research explores the case of a university, which, as mentioned earlier in the Methodology, is a leading private technology university in Vietnam; the technological facilities that students can get access to at this university may not be a representative scenario for higher education institutes in Vietnam in particular and many other EFL contexts in general. However, this research is not aimed to seek a generalization but to gain an insight into learners' perception and attitudes regarding gamification-related issues. The findings achieved in the current research are of values in informing teachers and educational administrators in the context of this study and similar EFL contexts about the potential of gamification as an emerging teaching approach.

\section{References}

[1] Bicen, H., \& Kocakoyun, S. (2018). Perceptions of Students for Gamification Approach: Kahoot as a Case Study. International Journal of Emerging Technologies in Learning (iJET), 13(02), 72-93. https://doi.org/10.3991/ijet.v13i02.7467

[2] Girard, C., Ecalle, J., \& Magnan, A. (2013). Serious games as new educational tools: how effective are they? A meta-analysis of recent studies. Journal of Computer Assisted Learning, 29(3), 207-219. https://doi.org/10.1111/j.1365-2729.2012.00489.x

[3] Zeynep, T., Zeynep, A., Kadir, K., \& Yuksel, G. (2016). Gamification and Education: Achievements, Cognitive Loads, and Views of Students. International Journal of Emerging Technologies in Learning (iJET), 11(07). https://doi.org/10.3991/ijet.v11i07.5455

[4] Trang, T. T., \& Baldauf, R. B. (2007). Demotivation: Understanding resistance to English language learning-the case of Vietnamese students. The Journal of Asia TEFL, 4(1), 79105.

[5] Nguyen, L. T. T. (2020). Integrating ICT Into Collaborative Writing: Are We Ready Yet? The Journal of AsiaTEFL, 17(1), 243-252. https://doi.org/10.18823/asiatefl.2020.17.1.16.2 $\underline{43}$

[6] Hamari, J., Koivisto, J., \& Sarsa, H. (2014). Does Gamification Work? - A Literature Review of Empirical Studies on Gamification. Paper presented at the 47th Hawaii International Conference on System Sciences, Waikoloa, HI. https://doi.org/10.1109/hicss.2014. $\underline{377}$ 
[7] Deterding, S., Dixon, D., Khaled, R., \& Nacke, L. (2011). From game design elements to gamefulness: defining "gamification". Paper presented at the The 15th International Academic MindTrek Conference: Envisioning Future Media Environment, Tampere, Finland. https://doi.org/10.1145/2181037.2181040

[8] Vidakis, N., Barianos, A. K., Trampas, A. M., Papadakis, S., Kalogiannakis, M., \& Vassilakis, K. (2019). Generating Education in-Game Data: The Case of an Ancient Theatre Serious Game. Paper presented at the Proceedings of the 11th International Conference on Computer Supported Education (CSEDU 2019). https://doi.org/10.5220/00078108003600 $\underline{43}$

[9] Vidakis, N., Barianos, K. A., Xanthopoulos, G., \& Stamatakis, A. (2018). Cultural Inheritance Educational Environment: The Ancient Theatre Game ThimelEdu. Paper presented at the European Conference on Games Based Learning.

[10] Simões, J., Redondo, R. D., \& Vilas, A. F. (2013). A social gamification framework for a K-6 learning platform. Computers in Human Behavior, 29(2), 345-353. https://doi.org/10. 1016/j.chb.2012.06.007

[11] Kalogiannakis, M., Nirgianaki, G.-M., \& Papadakis, S. (2018). Teaching magnetism to preschool children: the effectiveness of picture story reading. Early Childhood Education Journal, 45(5), 535-546. https://doi.org/10.1007/s10643-017-0884-4

[12] Papadakis, S., Vaiopoulou, J., Kalogiannakis, M., \& Stamovlasis, D. (2020). Developing and Exploring an Evaluation Tool for Educational Apps (ETEA) Targeting Kindergarten Children. Sustainability, 12(10), 4201. https://doi.org/10.3390/su12104201

[13] Papadakis, S. (2020). Evaluating a game-development approach to teach introductory programming concepts in secondary education. International Journal of Technology Enhanced Learning, 12(2), 127-145. https://doi.org/10.1504/ijtel.2020.106282

[14] Papadakis, S., \& Kalogiannakis, M. (2017). Using gamification for supporting an introductory programming course. the case of classcraft in a secondary education classroom. In A. L. Brooks, E. Brooks, \& N. Vidakis (Eds.), Interactivity, game creation, design, learning, and innovation (pp. 366-375): Springer. https://doi.org/10.1007/978-3-319-76908-0 35

[15] Barata, G., Gama, S., Jorge, J., \& Gonçalves, D. (2013). Improving participation and learning with gamification. Paper presented at the The First International Conference on Gameful Design, Research, and Applications - Gamification, Ontario, Canada. https://doi.org/10. $\underline{1145 / 2583008.2583010}$

[16] Moreno, J., \& Méndez, N. D. (2015). Teaching Sciences in K-12 using 2D Educational Massive Online Games. Anais temporários do LACLO, 10(1), 394-401.

[17] Kapp, K. (2012). The gamification of learning and instruction: Game-based methods and strat- egies for training and education., CA: San Francisco, CA: Pfeiffer.

[18] Egenfeldt-Nielsen, S. (2011). International survey on the experiences and perceptions of teachers. In S. Egenfeldt-Nielsen, H. H. Sorensen, \& B. Meyer (Eds.), Serious games in education: A global perspective. AArhus, Denmark: AArhus University Press.

[19] Mufidah, N. (2016). The effect of gamification on English language anxiety and grammar achievement. (Masters Master), Widya Mandala Surabaya Catholic University.

[20] Kayımbaşığlu, D., Oktekin, B., \& Hacı, H. (2016). Integration of Gamification Technology in Education. Paper presented at the 12th International Conference on Application of Fuzzy Systems and Soft Computing, ICAFS 2016, Vienna, Austria. https://doi.org/10.10 16/j.procs.2016.09.460

[21] Zou, D. (2020). Gamified flipped EFL classroom for primary education: Student and teacher perceptions. Journal of Computers in Education, 7(2), 213-228. https://doi.org/10.1 $\underline{007 / s 40692-020-00153-\mathrm{W}}$ 
[22] Henderson, A., Frost, D., Tergujeff, E., Kautzsch, A., Murphy, D., Kirkova-Naskova, A., Waniek-Klimczak, E., Levey, D., Cunningham, U. \& Curnick, L., 2012. 'The English pronunciation teaching in Europe survey: Selected results', Research in Language, vol. 10, no. 1, pp. 5-27. https://doi.org/10.1057/9781137509437_12

[23] Erenli, K. (2013). The Impact of Gamification - Recommending Education Scenarios. International Journal of Emerging Technologies in Learning (iJET), 8(1). https://doi.org/10. 3991/ijet.v8is1.2320

\section{Author}

Huyen Phuong is a lecturer of English who has involved in EFL teaching at different universities in Vietnam for the past 15 years. In 2018, Huyen gained her PhD degree in Applied Linguistics/TESOL at the University of Technology, Sydney, Australia.

Article submitted 2020-06-27. Resubmitted 2020-08-08. Final acceptance 2020-08-12. Final version published as submitted by the authors. 